\title{
Retratos de la guerra: glosas a propósito de Susan Sontag y el fotoperiodismo de Jesús Abad Colorado
}

Portraits of war: glosses on the subject of Susan Sontag and Jesús Abad Colorado's
photojournalism Andrés Felipe Ortiz Gordillo ${ }^{1}$
Universidad de Ibagué, Colombia
https://orcid.org/0000-0002-4524-8128
Giovanny Gilberto Leal Roncancio ${ }^{2}$
Universidad Nacional de Avellaneda, Argentina
https://orcid.org/0000-0002-2788-8826

Artículo de reflexión

Fecha de recepción: 1 de octubre de 2018 Fecha de aceptación: 11 de diciembre de 2018

\section{Para citar este artículo}

Ortiz Gordillo, A. F., y Leal Roncancio, G. G. (2019). Retratos de la guerra: glosas a propósito de Susan Sontag y el fotoperiodismo de Jesús Abad Colorado. Campos en Ciencias Sociales, 7(1), 195-225. DOI: https://doi.org/10.15332/25006681.4690

"Las fotos mías son historias de la gente".

Jesús Abad Colorado

1 Magíster en Estudios Sociales, alter comunicador, docente investigador de la Universidad de Ibagué e investigador del Colectivo de Estudios e Investigación Social - Proyecto CEIS. Integrante de la Fundación Medios al Derecho - MAD. Correo electrónico: andresfortizg@yahoo.es

2 Candidato a doctor en Ciencias Sociales de la Universidad Nacional de General Sarmiento (UNGS- IDES) Buenos Aires, Argentina, magíster en Estudios Políticos y comunicador social, docente de la Universidad Nacional de Avellaneda, UNDAV, e investigador del Colectivo de Estudios e Investigación Social - Proyecto CEIS. Correo electrónico: leal.giovanny@gmail.com 


\section{RESUMEN}

El artículo explora la obra del reconocido fotoperiodista colombiano Jesús Abad Colorado, quien se ha destacado por registrar los diferentes rostros, rastros y huellas del conflicto armado en Colombia, sobre todo en perspectiva de las víctimas, en diálogo con la filósofa y ensayista Susan Sontag. En este diálogo se exploran los regímenes de representación con los cuales se narran, desde la imagen, los conflictos armados contemporáneos. Para ello se reflexiona sobre el rol de la fotografía en la memoria de las sociedades contemporáneas y su influencia en las narrativas de la guerra, de las víctimas y de los combatientes, en un mundo donde los conflictos armados y sus imágenes globalizadas hacen parte de la existencia cotidiana de las sociedades.

Palabras clave: conflicto colombiano, fotoperiodismo, memoria colectiva, representaciones de la guerra.

\section{Abstract}

The article explores the work of well-known Colombian photojournalist Jesús Abad Colorado, who has distinguished himself by registering the different faces and traces of the armed conflict in Colombia, especially in the perspective of the victims, in dialogue with the philosopher and essayist Susan Sontag. In this dialogue, the representation regimes which narrate, from the image, contemporary armed conflicts are explored. To do so, this article reflects on the role of photography in the memory of contemporary societies and its influence on the narratives of war, of the victims and combatants, in a world where armed conflicts and their globalized images are part of the daily existence of societies.

Keywords: Colombian conflict, photojournalism, collective memory, representations of war. 


\section{INTRODUCCIÓN}

En el presente artículo se ponen en diálogo las obras y reflexiones de dos personajes, Susan Sontag y su trabajo sobre la fotografía de guerra y Jesús Abad Colorado, fotoperiodista de guerra que ha documentado el conflicto armado en Colombia. En un intento por entender lo que significa la relación entre estos dos escenarios, los debates que han tenido como centro esta relación y los aportes del fotoperiodismo a la reflexión del conflicto colombiano, se propone un diálogo que tiene como referentes de interpretación los asuntos de la memoria, la censura a la que se enfrentan las imágenes de guerra y el análisis de los regímenes de representación que se imponen como marco para la producción-creación, circulación e interpretación pública de las imágenes que documentan más de cincuenta años de guerra en Colombia, protagonizada por diferentes grupos armados, entre ellos, Ejército, Policía, guerrillas, paramilitares y carteles del narcotráfico.

Aquí el régimen de representación de la imagen hace alusión a los signos específicos del lenguaje (fotográfico) que posibilitan "hacer presente a los actores políticos (representantes y representados)" relacionados con una determinada actividad social (Fuenzalida, 2012, p. 84), en este caso, la guerra. Aquello que instituye el régimen de representación de la imagen son un conjunto de fuerzas, hegemónicas y subalternas, que batallan por la hegemonía de las formas de ver y de interpretar la imagen (en este caso la fotografía de guerra) en la sociedad, a partir del posicionamiento de dinámicas de poder.

En este sentido, el régimen de representación establece marcos particulares de producción e interpretación de significados sobre lo social, lo cual posibilita el establecimiento de formas específicas de observación de la realidad, producto de la correlación asimétrica de fuerzas que instituyen el debate sobre los diferentes aspectos constitutivos de lo social. Así, los regímenes de representación que actúan sobre las realidades sociales no lo hacen solo en el plano interpretativo, sino que involucran la producción misma de los referentes de la interpretación donde:

La realidad social impone a su vez las condiciones de su interpretación por los sujetos, sin que esto implique, por supuesto, un determinismo estricto. Las 
matrices socioestructurales y los entramados materiales en los que estamos inmersos definen nuestras rejillas de lectura, nuestras claves interpretativas y reinyectan en nuestra visión de la realidad una serie de condicionantes que reflejan nuestras inserciones en la trama socioeconómica y en el tejido relacional (Ibáñez, 1994, p. 165).

La representación caracteriza, entonces, un régimen de poder sobre la imagen por cuanto, como señala Jodelet, encarna "un conocimiento socialmente elaborado y compartido" (citado por Ibáńez, 1994, pp. 171-172), que permite a los sujetos sociales aprehender el sistema de relaciones en el que se encuentran inmersos para actuar, la mayoría de las veces en consecuencia a los marcos que establece este sistema. $Y$, por supuesto, la imagen fotográfica como artefacto sociocultural inserto en la trama de relaciones de lo social, no se escapa en sus elaboraciones e interpretaciones a la lógica de estos regímenes de representación.

Con el objetivo de evidenciar el régimen de representación, producción e interpretación de significados sobre la imagen, en el presente trabajo reflexivo se optó por aplicar una matriz metodológica que permitiera identificar en Sontag y Abad el rol que ambos ensayistas le otorgan a la fotografía en contextos de guerra o situaciones atroces, en tanto instrumento que posibilita significados en el momento de acceder a los hechos documentados en imagen. Por otro lado se busca reflexionar sobre las técnicas utilizadas para el registro de los hechos de guerra desde la imagen fotográfica.

A través de estos insumos se propone, entonces, un análisis de contenido donde algunos de los presupuestos de los autores dialogan, se complementan, se afirman y se interpelan, cada uno desde el lugar de enunciación que le corresponde: Sontag como filósofa de la imagen, y Abad Colorado como retratista de hechos relacionados con el conflicto armado colombiano.

Consideramos necesario en este punto hacer una corta semblanza de los autores, para poder comprender mejor su lugar de enunciación. Jesús Abad Colorado nació en Medellín, Colombia, en 1967. Periodista egresado de la Universidad de Antioquia, 
es uno de los fotógrafos que ha registrado de manera más exhaustiva el conflicto armado colombiano de las últimas décadas. Entre 1992 y 2001 trabajó como reportero gráfico para el periódico El Colombiano de Medellín. Durante su extensa carrera como fotoperiodista, ha escrito diversos libros, entre los que se cuentan: Relatos e imágenes: el desplazamiento forzado en Colombia (1997), Desde la prisión, realidades de las cárceles en Colombia (2006) y La casa, la calle, el barrio. Historias urbanas de reconciliación (2007). Ha sido también colaborador de revistas y libros de investigación social (Roca, 2001).

El trabajo fotográfico de Jesús Abad ha sido reconocido a nivel nacional e internacional con el Premio Internacional a la Libertad de Prensa (Nueva York, 2006) y el Premio Nacional de Periodismo Simón Bolívar (2001 y 2003), entre otros. Ha participado en más de cuarenta exposiciones individuales y colectivas, tanto en Colombia como en el exterior. Obtuvo los premios internacionales de Caritas, en Suiza, por su trabajo comprometido en la búsqueda de la verdad y la justicia social, y el Premio Internacional a la Libertad de Expresión CPJ de los Estados Unidos, otorgado por el Comité para la Protección de Periodistas, CPJ (Roca, 2001).

Susan Sontag, ensayista, filósofa, cineasta y activista social, nació en Nueva York, Estados Unidos, en 1933, y murió en esta misma ciudad en el año 2004. Su obra Ante el dolor de los demás (2003), es un ensayo que "defiende el derecho de los hombres a cerrar los ojos ante las imágenes de violencia que los asedian todos los días. Todos saben, sin embargo, que Sontag ha dedicado su vida a practicar exactamente lo contrario", dice su biografía publicada por el portal Biografias y vidas ${ }^{3}$.

Susan Sontag $(2003)^{4}$ entiende la fotografía como una especie de testigo privilegiado del sufrimiento que inflige la guerra sobre los hombres. Afirma que la repetición en imágenes de la perversión moral de la guerra puede acabar insensibilizando al espectador. Sin embargo, la fotografía también puede servir como dispositivo para denunciar el abuso, la crueldad y la barbarie, tantas veces como se produzcan. La fotografía es, entonces, instrumento de defensa de los sometidos por la guerra.

3 Ver: https://www.biografiasyvidas.com/biografia/s/sontag.htm

4 Las referencias de Sontag que se presentan en este artículo corresponden, fundamentalmente, a la obra Ante el dolor de los demás (2003), a menos que se indique lo contrario en la reseńa bibliográfica. 
La fotografía como testigo de la crueldad humana resulta, además, esencial para conservar la memoria frente a los actos de violencia y barbarie. La guerra constituye el marco en el que se dan los mayores fracasos de la condición humana, mientras que la imagen fotográfica, dice Sontag, juega un papel fundamental a la hora de producir un impulso moral en la sociedad, ya que permite reconstruir el panorama árido y frenético del sufrimiento causado en las guerras. ¿Qué sentimos cuando vemos imágenes fotográficas de la guerra: un hombre sonriente que dispara a otro en la cabeza; cuerpos de niños, niñas, hombres y mujeres destrozados por un bombazo o por un machete?

La manera más resuelta de compensar la conmoción interior que producen las fotografías del conflicto armado cuando son expuestas públicamente, consiste en poner en duda o sacar de contexto aquello a lo que la imagen remite, oscureciendo sus referentes. Sontag señala que las fotografías de las víctimas de la guerra son, en sí mismas, una especie de retórica, ya que reiteran, simplifican y agitan la sensibilidad humana y, bajo este régimen de representación, crean la ilusión de consenso frente a la guerra y sus motivaciones. Lo que en definitiva dejan ver estas imágenes es cómo "la guerra expulsa, destruye, rompe y allana el mundo construido" (Sontag, 2003, p. 14 ), aunque no ofrecen prueba alguna para renunciar a la guerra, ya que conceptos vinculados a ella, como valentía y sacrificio, han sido despojados de su sentido y legitimidad.

La vida moderna depara al sujeto social incontables oportunidades de mirar el dolor de otras personas con la suficiente distancia como para no ser ni sentirse víctima. Las reacciones a la imagen fotográfica son contradictorias, ya que pueden generar indignación y llamados de paz, al tiempo que permiten producir sentimientos de venganza y conflagración:

¿Quién puede olvidar las tres fotos en color de Tyler Hicks que The New York Times presentó a lo ancho de la primera plana, en la parte superior de su sección diaria dedicada a la nueva guerra de Estados Unidos, "Una nación desafiada", el 13 de noviembre de 2001? El tríptico representaba el destino de un soldado talibán de uniforme, herido, que soldados de la Alianza del Norte 
en su avance hacia Kabul habían hallado en una cuneta. Primer panel: dos de sus captores lo arrastran sobre el dorso - uno lo ha cogido del brazo, el otro de una pierna- por un camino pedregoso. Segundo panel (la cámara está muy cerca): rodeado, mira hacia arriba con terror mientras tiran de él para erguirlo. Tercer panel: el instante de la muerte, supino con los brazos extendidos y las rodillas dobladas, desnudo y ensangrentado de cintura para abajo, lo remata la turba militar que se ha reunido para masacrarlo (Sontag, 2003, p. 10).

Las formas como se ha representado el conflicto colombiano mediante el fotoperiodismo, y en general desde el uso de imágenes -fijas y en movimientoen el espacio público de los medios de comunicación, obliga a la identificación de los regímenes de representación a partir de los cuales se ha contado la guerra en Colombia. Hay que señalar que una de las características más relevantes del tratamiento informativo fotográfico colinda con expresiones de censura, donde la guerra, sus actores, sus impactos y sus intereses, se "estetizan" y por extensión, se banalizan, se expectacularizan, es decir, se sustrae de los sentidos y el dolor de quienes viven y sienten los efectos de la guerra, de su propia realidad y se le confieren nuevos valores, más cercanos a las estéticas hollywoodenses que a los dramatismos de la condición humana.

La imagen fotográfica se debe entender, entonces, como artefacto epistémico, cultural y comunicativo que posibilita la representación social de la guerra, y que convive con los regímenes de representación a partir de los cuales se sustentan las hegemonías sociopolíticas y económicas que promueven el conflicto (desde el plano de lo simbólico, para este caso). Estos regímenes de representación se expresan, entre otras maneras, por medio de la censura como escenario de restricción simbólica del conflicto hecho imagen.

En contraposición, a partir del análisis de la obra fotográfica también se pueden explorar los modos como se representan las acciones de recuperación de la memoria como asunto ético, los sentidos que el fotoperiodismo crítico puede formular a los contextos de conflicto armado, entendiéndose la imagen fotográfica como síntesis del "dolor de los otros", en respuesta a la banalidad, la carencia de sentido y el deterioro que enfrenta la imagen contemporánea como dispositivo de denuncia social. 


\section{Metodología}

El presente artículo de reflexión propone un diálogo entre los análisis de la fotografía de guerra sintetizados en el libro Ante el dolor de los demás (2003) de Susan Sontag, y la obra del fotoperiodista colombiano Jesús Abad Colorado. Así, tanto el documento de Sontag como parte de la obra de Colorado (fotografías paradigmáticas y entrevistas realizadas al fotoperiodista, cuyo tema central está relacionado con el conflicto armado colombiano entre las décadas de 1990 y 2000) son asumidos como unidades de análisis que posibilitan sintetizar reflexiones sobre las gramáticas de representación de los conflictos armados, y sobre la manera como la fotografía, entendida como texto sociopolítico, es interpretada desde regímenes de representación instituidos.

Teniendo en cuenta este propósito, el artículo atiende a las premisas metodológicas del "análisis de contenido" desde una dimensión socioideológica, en la que se identifican "los posibles significados que se le pueden atribuir al mensaje transmitido" (Fernández, 2002, p. 36). Se asume aquí el análisis de contenido desde la perspectiva de Díaz y Navarro (1998), quienes lo definen como:

Un conjuto de procedimientos que tienen como objetivo la producción de un metatexto analítico en el que se presenta el corpus textual de manera transformada. [...] $\mathrm{O}$, dicho de otro modo, ha de concebirse como un procedimiento destinado a desestabilizar la inteligibilidad inmediata de la superficie textual, mostrando sus aspectos no directamente intuibles y, sin embargo, presentes (Díaz y Navarro, 1998, pp. 181-182, citados por Fernández, 2002, p. 37).

El análisis se aborda con intenciones connotativas más que denotativas, por cuanto busca dirigir la atención sobre las formas como se introduce la fotografía en la conversación social del conflicto armado. Por supuesto que ello obliga referencias denotativas sobre la imagen fotográfica, pero el interés se concentra en su significado y en la gramática interpretativa del conflicto que ella posibilita, teniendo en cuenta además los condicionamientos sociopolíticos (regímenes de representación) que determinan la interpretación social de la guerra vista desde la obra fotográfica, ya que aunque a la fotografía se le quiera hacer aparecer socialmente como mensaje que 
"denota” la guerra, ella adquiere múltiples sentidos que conllevan, "además de su sentido propio o específico, otro de tipo expresivo o apelativo" (DRAE, 2017). Por lo tanto, se reconoce que el fotoperiodismo del conflicto armado:

Es un objeto trabajado, escogido, compuesto, elaborado, tratado de acuerdo con unas normas profesionales, estéticas o ideológicas que constituyen otros tantos factores de connotación; por otra parte, esa misma fotografía no solamente se percibe, se recibe, sino que se lee (Barthes, 1986, p. 15, citado por Marfil-Carmona, 2015, p. 501).

En este sentido, para realizar el análisis de contenido se optó por identificar en ambos ensayistas el rol que puede llegar a ocupar la fotografía en medio de contextos de guerra o situaciones violentas, en tanto instrumento que transmite un mensaje, pero que a su vez es objeto de posibles significados en el momento de acceder al acontecimiento que se documenta en imagen. A su vez, se seleccionaron en el documento de Sontag como en parte de la obra de Abad (fotografías y entrevistas realizadas al fotoperiodista), las técnicas utilizadas para el registro de los hechos desde la imagen fotográfica.

Así que el rol de la fotografía en contextos de guerra o hechos atroces y las técnicas de registro de dichos hechos a través de la fotografía, son la matriz analítica utilizada para entablar un diálogo entre Sontag y Abad, dos ensayistas con diferencias de época y experiencia, pero que desde el quehacer de cada uno se encuentran en un punto común, la fotografía como instrumento que posibilita la reflexión de los hechos atroces y de guerra.

\section{La constitución de los regímenes de representación fotográfica de la guerra}

En 1924 el objetor de consciencia Ernst Friedrich publicó el libro Guerra contra la guerra, una colección de más de ciento ochenta imágenes conseguidas de archivos médicos y militares alemanes. Susan Sontag (2003) afirma que entre la apertura y el cierre del libro: 
El lector emprende un atormentador viaje fotográfico a través de ruinas, matanzas y degradaciones: páginas de castillos e iglesias destruidos y saqueados, pueblos arrasados, bosques asolados, vapores de pasajeros torpedeados, vehículos despedazados, objetores de conciencia colgados, prostitutas semidesnudas en burdeles militares, tropas agonizantes después de un ataque con gas tóxico, niños armenios esqueléticos... (p. 11).

De todo lo esperpéntico que se muestra en Guerra contra la guerra, hay apartados especiales dedicados a la muerte de los soldados de distintos ejércitos: los cuerpos se descomponen en los campos, en los caminos y en las trincheras del frente de guerra. Otro de los materiales "más insoportables del libro", dice Sontag, es un conjunto de fotografías que se encuentran en la sección titulada "El rostro de la guerra". Allí aparecen veinticuatro primeros planos de soldados con enormes heridas en sus rostros.

La obra fotográfica de Jesús Abad se ha caracterizado por tener una mirada que valora la humanidad que se esconde, incluso, en los rostros de los guerreros. Abad asegura que le interesa tomar distancia del uso de la fotografía como espectáculo; no quiere que sus fotografías sirvan para satisfacer una curiosidad morbosa sobre los hechos del conflicto colombiano. Jesús Abad es considerado, por colegas y espectadores de su obra, como un relator de historias, un periodista que atestigua con su lente el desastre y la desolación, pero a la vez la resistencia y la fortaleza de la gente y de comunidades enteras que viven en medio de la guerra.

La obra de Jesús Abad Colorado aspira a recuperar la memoria del presente, porque para él, la memoria histórica que se traduce en sus fotografías son también un referente ético que posibilita proyectar nuevos futuros: "Es un trabajo continuo contra el olvido. Utilizo la fotografía como documento social y político, para buscar cambios de actitud en un país insensible frente al dolor de las víctimas", señala el fotorreportero (Cuevas, 2012).

Dice Jesús Abad que la forma como se registra informativamente el conflicto en Colombia es banal y carente de sentido; se ha trivializado el dolor que producen los 
hechos de violencia. Explica que esas situaciones han sido tan repetitivas a lo largo de más de cinco décadas de conflicto social y armado que, por ejemplo, la pobreza como producto del desplazamiento forzado dejó de ser noticia, y los asesinatos solo llaman la atención si son colectivos, si constituyen una masacre: "Digamos que se cumple como un efecto de adormecimiento, porque no sorprenden los hechos de barbarie de nuestro país" (Águila, 2006).

$\mathrm{Al}$ respecto, Sontag trabaja la idea del agotamiento de la fuerza de la imagen, sostiene que la frecuencia y las formas con que se expone la fotografía socialmente, terminan agotando la fuerza de la imagen, tarde o temprano dichas imágenes terminan empalagando. Es desde este punto de vista que la ensayista explica lo que llamamos insensibilidad, porque la fotografía así como la televisión, incitan a saciar la atención del público receptor de las imágenes de violencia y de guerra.

Como en el caso de Ernst Friedrich y su libro, la exhibición pública de las fotografías genera reacciones de los Gobiernos y las organizaciones de excombatientes, quienes manifiestan su inconformidad sobre la manera como se muestra la guerra; denuncian el uso público de las imágenes, al punto de generarse acciones contra la exhibición de dicho material, el cual es celebrado por escritores, artistas e intelectuales críticos, así como por miembros de ligas contra la guerra, ya que el material permite conocer "realmente" los impactos de la guerra sobre la humanidad de los combatientes.

La publicación de la fotografía de guerra no pretende solamente "mostrar", también quiere influir en la opinión pública para frenar aquello que precede a la imagen: la guerra. Las diferentes representaciones de las guerras persiguen, de alguna manera, generar consciencia de todo aquello que antecede al acontecimiento bélico, de lo que lo hace posible, de lo que lo legitima como conducta social aprobada. Esto supone que la representación social de la guerra es una construcción social intencionada.

Para Sontag, los diferentes registros de la guerra dependen, por ejemplo, de la forma en que los lentes registran el acontecimiento: las cámaras destellan por un momento sobre lo sucedido, luego la fotografía es revelada, es decir, aparece socialmente y, al final, desaparece de la vista. La fotografía tiene un lenguaje "en potencia": es todo 
lo que se pueda inferir de ella en contexto o por fuera de él. La fotografía es lo que enmarca (aquello que logra aparecer en la imagen) y también lo que desborda (todo lo que no aparece explícitamente, pero que se infiere del relato icónico que presenta).

Abad es un fotógrafo crítico de la forma como se registran los hechos bélicos. El cubrimiento del conflicto exige un registro que contribuya con la identificación y reflexión de los contextos, factores y actores que han posibilitado la guerra, donde se asuman modos de producción informativa en las que

[...] las imágenes no se le hagan a los muertos. Las imágenes hay que hacerlas en el rostro de los vivos. Cuando tú ves el rostro de los vivos y les ves las manos o sus pies, o ves los rostros de los huérfanos, vas a entender el dolor de una guerra, que es el mismo en el Medio Oriente o en Colombia, porque siempre van a perder los mismos: los pobres (Águila, 2006).

Esto se evidencia en fotografías como "Barrio La Independencia"; en ella aparecen la vida y la muerte, una violencia que rompe las fronteras entre lo público y lo privado. Ahora la violencia llega a las casas y entra en ellas de diferentes maneras, sin que la sociedad civil inmersa en el conflicto pueda ser algo más que espectadora de la tragedia social. 
Fotografía 1. Jesús Abad Colorado (2002), Barrio La Independencia, Comuna 13, Medellín.

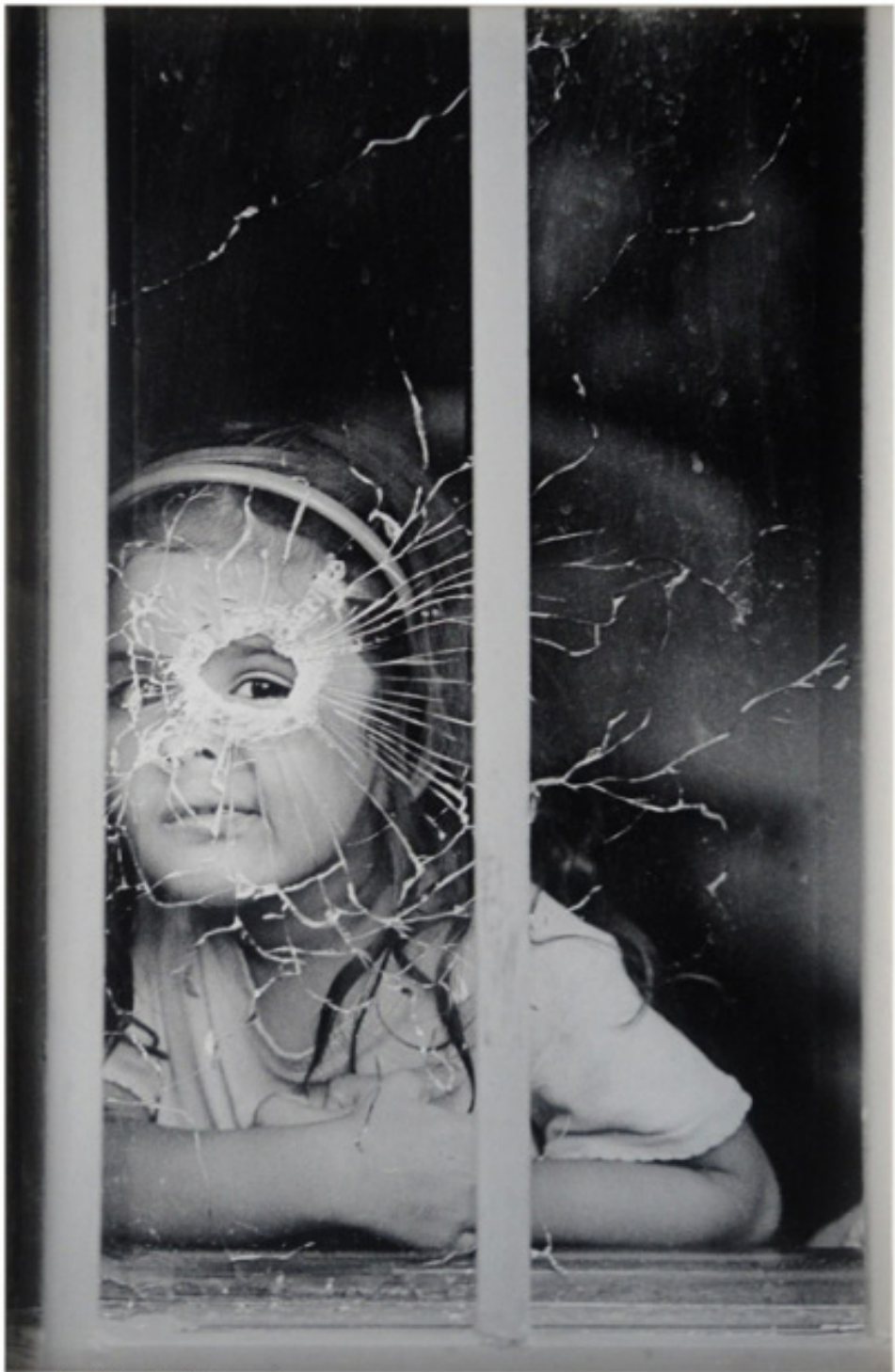

\section{Jesús Abad Colorado}

Barrio La Independencia, Comuna 13, Medellín 2002

Fotografía blanco y negro impresa en papel algodón Hahnemühle $90 \times 60 \mathrm{~cm}-357 / 16 \times 235 / 8$ in 
Sontag a su manera coincide en la necesidad de entablar un vínculo más reflexivo con el contenido de la fotografía, con el fin de permitir ampliar los sentidos que rodean las imágenes de guerra, porque para la ensayista es necesario que no se apacigüen los sentimientos que generan las imágenes atroces y por ello, considera que es necesario asumir una intensidad de la atención. Es por ello, que propone permitir que las imágenes inhumanas nos persigan, de tal manera, que se logre romper con el defecto moral de ignorancia o amnesia que trae consigo el hartazgo de imágenes violentas o de guerra.

De este modo, se trata entonces de comprender que las imágenes atroces o de guerra, inciten a prestar atención desde una perspectiva reflexiva, hacia los hechos que se documentan y sobre los sentidos y sentimientos alrededor del sufrimiento y sus formas de representación de dichas imágenes. Aquí un punto de coincidencia entre Sontag y Abad, en torno a la necesidad de reflexionar los contextos, factores y actores que han posibilitado dichas imágenes atroces o de guerra, así como la forma y las técnicas utilizadas para el registro de los hechos desde la imagen fotográfica.

En el acontecimiento fotográfico, diría Sontag, el asunto del desarrollo tecnológico es un factor importante. En las primeras guerras importantes de las que los fotógrafos dieron cuenta (desde la guerra de Crimea y la guerra de Secesión de Estados Unidos hasta la Primera Guerra Mundial), el combate mismo estaba fuera del alcance de la cámara. La mayoría de las imágenes eran anónimas y, por lo general, transmitían parte del "terror y la devastación" que resulta de los enfrentamientos; también presentaban el deterioro de los campos de guerra y los cadáveres esparcidos dentro y fuera de las trincheras. La fotografía mostraba los resultados de la guerra, pero no los instantes de su desarrollo. Y mostraban lo que se permitía mostrar:

La observación fotográfica de la guerra tal como la conocemos, tuvo que esperar unos cuantos años más para que mejorara radicalmente el equipo fotográfico profesional: cámaras ligeras, como la Leica, las cuales usaban una película de treinta y cinco milímetros que podía exponerse treinta y seis veces antes de que hiciera falta recargarlas. Ya se podían hacer fotografías en el fragor de la batalla, si lo permitía la censura militar, y se podía estudiar de cerca a las víctimas civiles y a los tiznados y exhaustos soldados (Sontag, 2003, p. 14). 
Sontag da un valor importante al aspecto material de la imagen fotográfica, ya que desde que se inventó la cámara, en $1839^{5}$, la fotografía ha acompañado a la muerte. La imagen producida por una cámara es, literalmente, el rastro de algo que se presenta ante la lente, la evocación de lo que va siendo, de lo que materialmente existe, incluyendo la muerte:

\begin{abstract}
Al emanciparse del trípode, la cámara se hizo en verdad portátil y, equipada con telémetro y diversas lentes que permitieron inauditas hazañas de observación próxima desde un lugar lejano, hacer fotos cobró una inmediatez y una autoridad mayor que la de cualquier relato verbal en cuanto a su transmisión de la horrible fabricación en serie de la muerte (Sontag, 2003, p. 15).
\end{abstract}

Una de las primeras guerras fotografiadas en detalle fue la Guerra Civil Española (1936-1939). El registro fue realizado por un equipo de fotógrafos profesionales que se encontraban en la línea de las acciones militares y en los pueblos bombardeados. Algo similar ocurrió con la guerra que Estados Unidos libró en Vietnam, la cual fue registrada día tras día por cámaras fotográficas y de televisión, lo que permitió a la opinión pública observar la muerte y la destrucción en el frente interno. "Desde entonces, las batallas y las masacres rodadas al tiempo que se desarrollan han sido componente rutinario del incesante caudal de entretenimiento doméstico de la pequeña pantalla” (Sontag, 2003, p. 14).

Este tipo de registros logran crear una consciencia de la guerra tanto para los que la viven (porque participan de ella como combatientes o como víctimas civiles directas), como para los que la ven. Pero mientras las imágenes audiovisuales de la guerra proponen un "discurso de actualidad informativa" para la gente que no vive el conflicto armado y sus consecuencias, a la fotografía se le otorga, según Sontag, la función de ser referente para el recuerdo. Mientras las imágenes de televisión, el video continuo y las películas se convierten en la imagen superficial que muestra y “actualiza la actualidad” bélica, la fotografía cala en lo más profundo del recuerdo y la memoria.

5 Esta fecha es discutida por algunos expertos en historia de la fotografía. José Luis Pariente señala, por ejemplo, que: "el hecho de haber escogido el año de 1839 como el del inicio de la fotografía obedece (a causas) más oficialistas y burocráticas que propiamente fotográficas”. Ver: Pariente (s. f.) 
Quizás la gran diferencia entre Sontag y Colorado es que ella propone que las imágenes atroces nos persigan con el fin de romper con la amnesia de los hechos de guerra que se documentan, mientras que Jesús Abad propone, en cierto sentido, un oxímoron, ya que busca contar "el lado humano de guerra", desde el retrato de los rostros y rastros de los diferentes actores que confluyen en el conflicto colombiano, y desde los rostros, rastros y relatos de vida de las víctimas, representando el dolor humano de miles, de millones de colombianos que son los perdedores de siempre, el pueblo pobre y olvidado:

Los ejércitos manipulan armas, pero las personas que las manipulan son sencillas y son pobres. Los rostros de los campesinos que integran las guerrillas, son los mismos rostros de los soldados, de los muchachos de los grupos paramilitares. Es el mismo pueblo pobre que está portando las mismas armas... (Águila, 2006).

Sobre este punto, para Sontag la representación del dolor humano y sus significados es propia del proceso de saturación de la atención de las imágenes atroces, desde una perspectiva reflexiva, así todo lo anterior termina siendo el producto de esta forma particular de enfrentar y digerir lo que las imágenes violentas o de guerra proponen mas allá de lo que se documenta. Por su parte, Abad llega al mismo punto e interés de Sontag, pero a través de su práctica de fotografiar y documentar las consecuencias de los hechos de violencia y la guerra, a través de los rostros y los rastros de las víctimas.

Aquí pueden observarse dos formas distintas de concebir las fotografías y las imágenes atroces, pero también un punto de coincidencia en torno al rol de la fotografía como catalizador de la reflexión, porque permite la ampliación de los significados y el contexto sobre el sufrimiento y el dolor humano, y sobre las profundas contradicciones de la guerra, como aquella en la que junto a un letrero que dice: "No maltrate a los nińos, son el futuro", se ve a una adolescente combatiente de las Fuerzas Armadas Revolucionarias de Colombia, FARC-EP, en la antigua zona de distención que la guerrilla negoció con el Gobierno del presidente Andrés Pastrana (1998-2002), en uno de los intentos de negociación de la paz en Colombia. 
Fotografía 2. Jesús Abad Colorado (2000). San Vicente del Caguán, Caquetá.

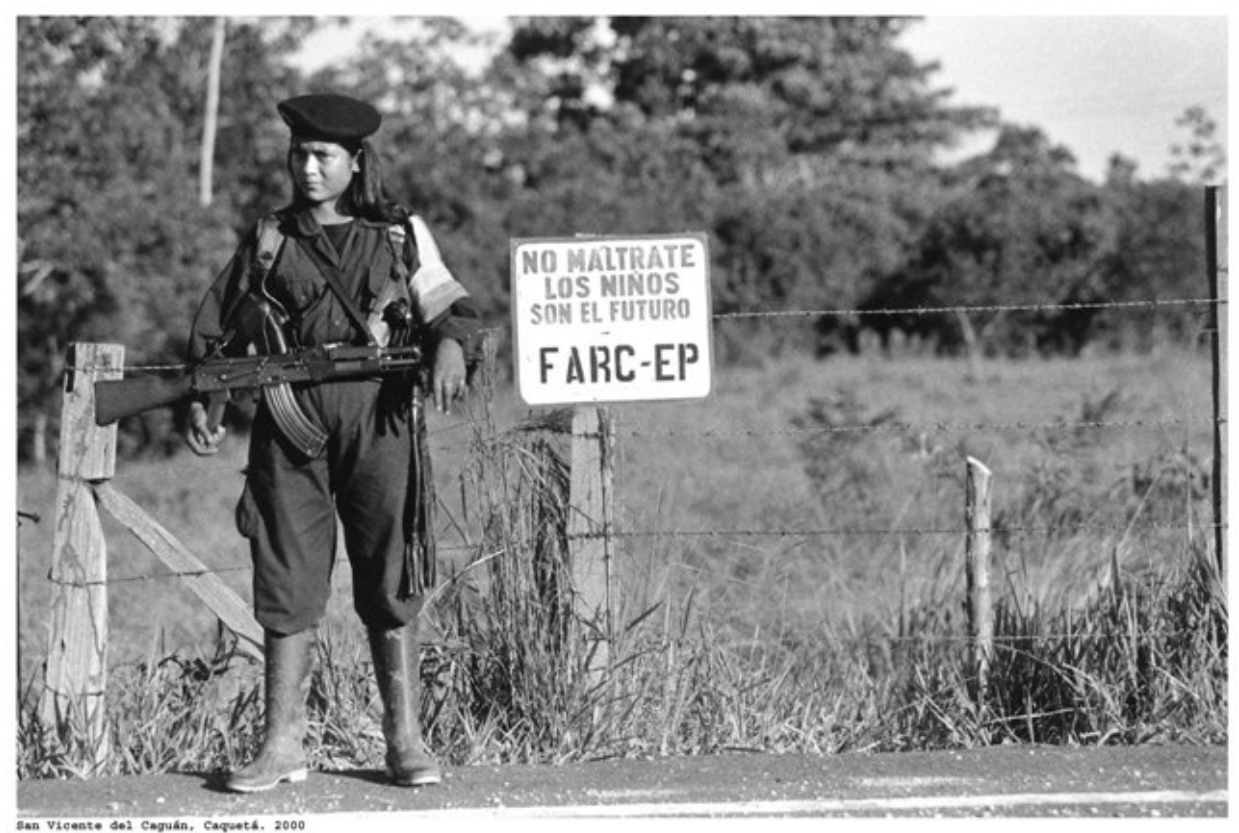

La fotografía se ha convertido, entonces, en atributo ineludible de nuestro conocimiento de la guerra mediado por la cámara. Así, la fotografía ofrece un modo expedito de comprensión social en perspectiva histórica, ya que en tanto dispositivo social es un medio de memorización. Sontag diría que la fotografía almacenada es como una cita, ya que se dispone de la imagen para mostrar algo del pasado que adquiere vigencia en el presente.

Las fotografías son asumidas como "el registro de lo real", es decir, algo incontrovertible, porque ofrecen testimonio de lo innegable, puesto que además de la imagen tuvo que haber una persona, un testigo, que sintetizó en imágenes su vivencia. La fotografía es, entonces, testimonio y prueba de la realidad. Pero también es "simplemente la burda expresión de un hecho dirigido a la vista” (Woolf citada por Sontag, 2003, p. 16). Se comienza a poner en cuestión la objetividad de la fotografía. 
Después de la Segunda Guerra Mundial, las tendencias para la interpretación de las fotografías transitan entre el registro objetivo y el testimonio personal, entre la transcripción o copia fiel de un momento efectivo de la realidad y la interpretación subjetiva e intencionada de esa realidad. Se ponía en cuestión el hecho de que las fotografías eran imágenes resultado de la orientación y el trabajo previo que realiza quien administra el dispositivo tecnológico, la cámara. Y también de una vocación estética y política (incluso ideológica) que acompaña el acontecimiento de registro. De ello se desprende que en toda interpretación de la imagen fotográfica hay que reconocer el carácter subjetivo.

Esta discusión pone en duda el "componente estético" de la fotografía de guerra: para el caso del registro de acontecimientos de violencia, las imágenes parecen más auténticas cuando su iluminación y composición son precarias: "al volar bajo, en sentido artístico, se cree que en tales fotos hay menos manipulación”, señala Sontag (2003, p. 16), subrayando que las fotografías menos estetizadas son bien recibidas y adquieren una especial autenticidad, reconociéndose la existencia de factores como el azar, y la inclinación por lo espontáneo, lo tosco, lo imperfecto.

Los regímenes de representación social de la imagen, a la larga, suponen una interpretación desde lo que debería estar diciendo la fotografía. Desde el período de entreguerras y con mayor fuerza después de la Segunda Guerra Mundial, se consolida el debate sobre la misión ética de los fotoperiodistas como cronistas de su tiempo, sea en tiempos de paz o de conflicto. Ello les endilga la responsabilidad de ser testigos imparciales, sujetos libres de prejuicios patrioteros. Sin embargo, tal como reseña Sontag, se reconoce que las intenciones del fotógrafo no determinan obligatoriamente la significación de la fotografía, ya que esta seguirá su propia carrera por las diversas comunidades interpretativas, que serán las que le encuentren alguna utilidad específica a la imagen, en relación con sus intereses, sin entender necesariamente que fotografiar es encuadrar, y encuadrar es excluir.

Siempre ha sido posible que una fotografía tergiverse las cosas que representa. En contraste a su condición de reproductora objetiva de la realidad, la fotografía no solo muestra, sino que también evoca y puede convertirse en truco que falsifica el 
acontecimiento histórico, lo que la hace un recurso impuro, como casi todos los recursos y las pruebas históricas. $\mathrm{Y}$ aun con esto, la fotografía se instituye como evidencia infalible de la realidad, como manifestación y comprobación de los hechos. Allí está su certeza y su engaño, pero también su autenticidad y su diatriba. En este sentido, lo que subyace de fondo, es el problema del acceso al acontecimiento en sí mismo, por ello el impacto de la imagen fotográfica es a la vez epistémico, cultural y político.

En los más de veinticinco años que lleva retratando el conflicto armado colombiano, Jesús Abad asegura que es aterrador no solo lo que ha visto como producto fáctico de la guerra, sino también la manera como la dirigencia política y económica del país posibilita estos actos. Horrenda también la indiferencia de la sociedad que no se conmueve con el dolor de los otros: "Es aterrador. Los hechos deberían producir vergüenza, no solo entre los 'actores de la guerra', sino también entre los dirigentes que posibilitaron su recrudecimiento y entre una sociedad que no se ha conmovido frente al dolor de los otros" (Cuevas, 2012).

Jesús Abad asegura que le interesa generar reflexión y no espectáculo: "Es mejor una foto respetuosa y digna de las víctimas, que una que genere odio o sed de venganza" (Cuevas, 2012). Este pensamiento permite dar cuenta de su estilo y de la mirada que ha construido sobre el cubrimiento del conflicto, en la que se busca resaltar la vida en medio del horror, porque en esos rostros se encuentran las historias de aquellos que siguen viviendo esperanzados, mientras llevan a cuestas las marcas de la guerra, como lo evidencian las madres y abuelas de Bojayá, Chocó, luego de la masacre cometida por las FARC que, en enfrentamientos con grupos paramilitares, mataron de un solo bombazo a 79 personas. Aquí Abad no muestra los cuerpos destrozados por el "cilindro bomba", sino la tristeza, y también la dignidad, de quienes quedaron vivos. 
Fotografía 3. Jesús Abad Colorado (2002). Masacre de Bojayá, Chocó.

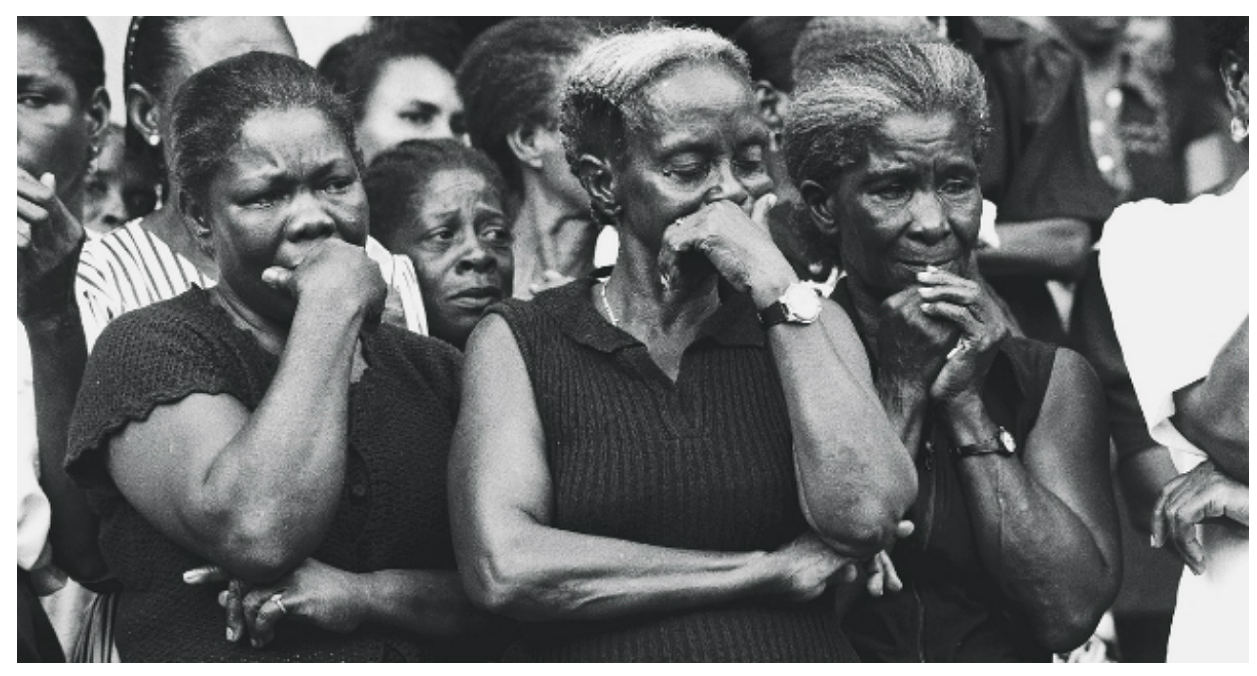

\section{El hastío de la imagen: entre la memoria y el olvido}

A Jesús Abad Colorado le indigna la superficialidad de los medios de información con respecto al cubrimiento del conflicto colombiano; asegura que existe desinterés por mostrar las historias de la gente que vive el conflicto social y armado en Colombia. Esto se convierte en motor de su trabajo, ya que confirma la necesidad que tiene el fotógrafo de ir a donde está la gente victimizada por los actores armados (oficiales y no oficiales), de caminar con ella, de ver y sentir lo que significa estar en medio de la guerra:

La historia de un país y su testimonio en fotos no se hace desde una oficina o por teléfono. Los reporteros debemos caminar un poco más, para buscar la verdad y estar cerca de la gente. Y lo hago además porque da tristeza que en la balanza noticiosa de este país sea prioridad el cubrimiento de un reinado o un partido de fútbol, y no la vida de sus campesinos (Cuevas, 2012).

El asunto tiene que ver con los contextos en los que se presenta la imagen fotográfica que muestra las luchas sociales. A los indígenas y campesinos del departamento del 
Cauca, uno de los lugares del país donde más se concentran los conflictos sociales vinculados a la tierra, se les ha mostrado como bandoleros y terroristas. Las imágenes de este conflicto sustraen la discusión y las disputas históricas sobre la propiedad y administración de la tierra, y la colocan en el plano coyuntural de la "situación de orden público" que justifica a la opinión pública las intervenciones militares sobre el territorio y en contra de las comunidades.

Fotografía 4. Jesús Abad Colorado (1999). Toma de la vía Panamericana en el Cauca por parte de campesinos e indígenas.

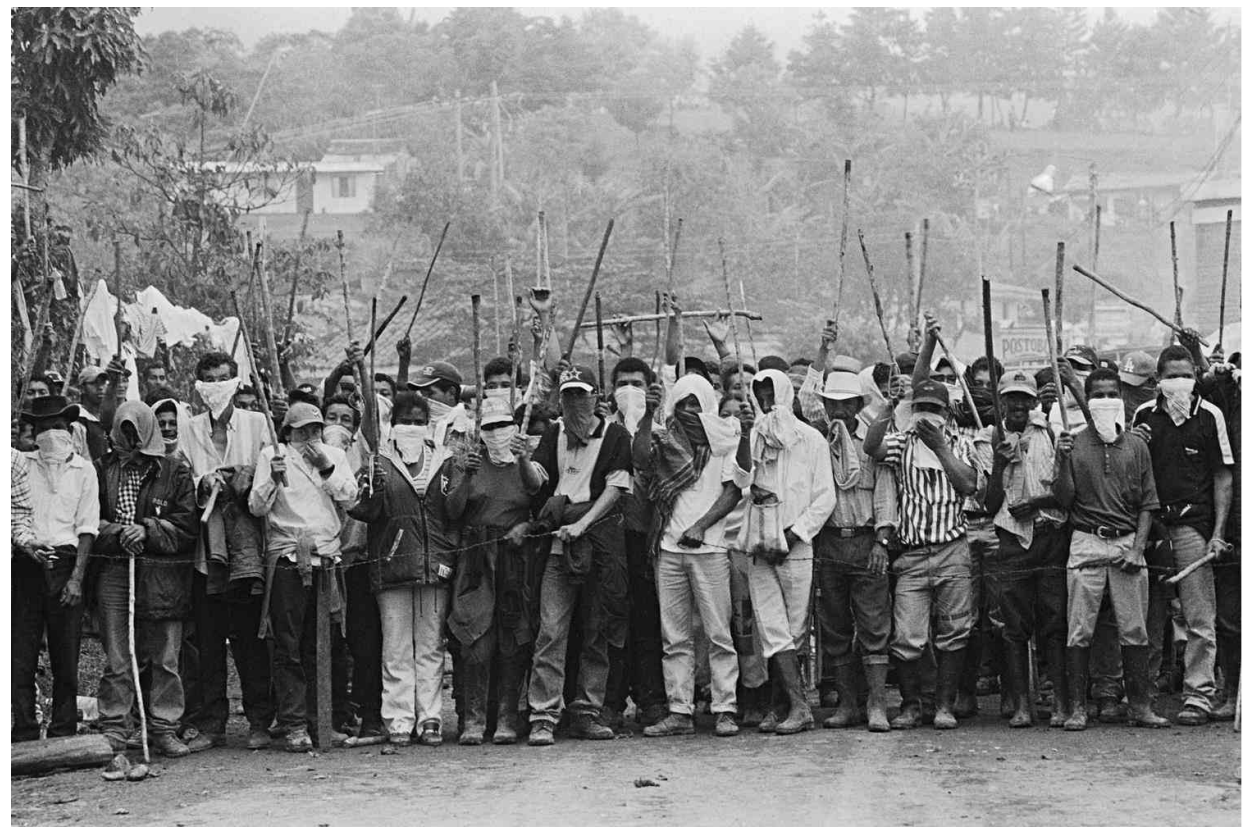

La fotografía de guerra se enfrenta, entre otros problemas, a uno fundamental: la censura. En la primera guerra del Golfo Pérsico, los estadounidenses introdujeron la idea de "tecnoguerra", donde los espectadores pudieron observar en vivo una suerte de espectáculo pirotécnico, cuya distancia no permitía ver buena parte de los estragos que produjo la incursión armada: cuerpos mutilados, edificios destrozados, civiles despojados de todo derecho en nombre de la defensa de los derechos humanos. 
La censura camuflada proyectó en la opinión pública un nuevo tipo de guerra, más vinculada con la producción hollywoodesca de la sociedad del espectáculo, banal y poco detallada, que con la realidad misma de los conflictos bélicos. Aquí la fotografía no ofrece testimonio de lo desastroso y reprensible de la guerra; al contrario, se presenta con una estética particular, presume de dotes artísticas sin que refiera en concreto a los dramas humanos y sociales que genera, de facto, la guerra.

Las fotografías ayudan a erigir y a revisar nuestro sentido del pasado más lejano. Sontag señala que las fotografías que reconocemos en la actualidad son parte constitutiva de lo que como sociedades hemos elegido tener como referentes de reflexión y acción. Pero la fotografía no interpela solo la memoria, también interpela la mirada misma. Pregunta Sontag si se puede sentir obligación de mirar fotografías que registran grandes crueldades y crímenes.

Las imágenes que reflejan las crisis de las sociedades por la vía de retratar sus expresiones de violencia son, a la vez, atractivas y repulsivas, pueden también fascinar por la curiosidad que despiertan (¿quién era ese sujeto?, ¿por qué aparece despedazado su cuerpo?, ¿qué sentía ese cuerpo-sujeto en el momento en que se tomaba la fotografía?, ¿qué sentía el fotógrafo?) Y ¿qué hacer entonces con esos sufrimientos que retratan las imágenes de la guerra?

Muy al contrario de las lógicas de producción de los medios masivos hegemónicos, a Jesús Abad le interesa la denuncia del conflicto, y la denuncia de la manera como se cuenta y se representa el conflicto. Como Sontag, Jesús Abad reflexiona sobre la obligación de pensar en lo que implica mirar la crueldad retratada, esto es, reflexionar sobre la manera como las sociedades observan el mundo, y sobre cómo lo representan, cuestión que no es considerada como relevante en el ejercicio de producción de imágenes que sobre el conflicto se ejecuta desde las hegemonías comunicativas. Con todo, Abad Colorado señala que:

No soy un hombre de fotografías espectaculares. Yo no pongo a la gente a posar para ponerla a llorar. Yo hago fotos sencillas y humanas, dignas. Yo no estudié fotografía, yo estudié periodismo. Yo no he hecho cursos de iluminación, no 
he hecho cursos de Photoshop, para ver qué puedo manipular, qué puedo borrar. No. Las fotos mías son historias de la gente. Eso son (Sánchez, 2017).

Fotografía 5. Jesús Abad Colorado (2001). Municipio de Peque, Antioquia.

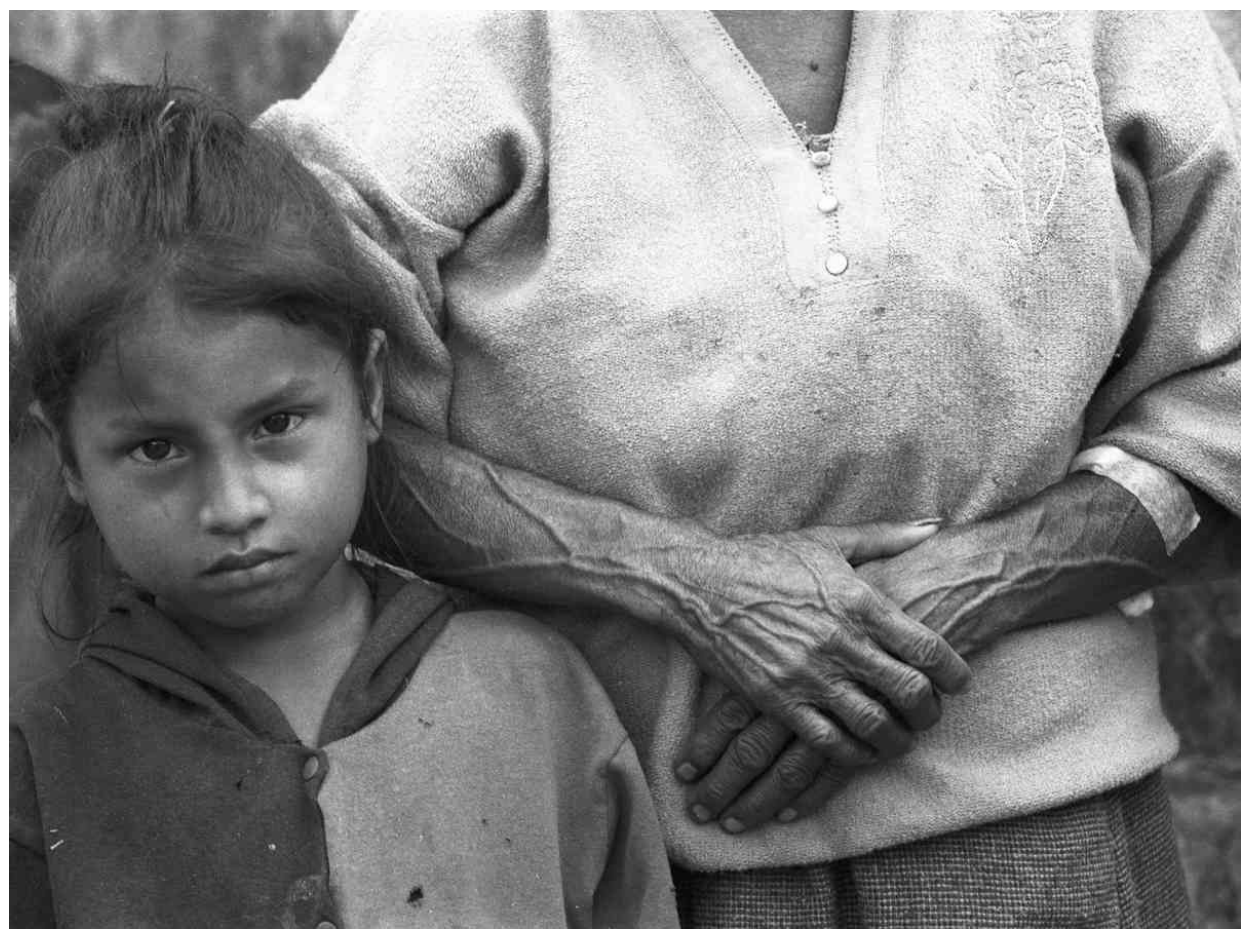

En confluencia con los análisis de Abad, para Sontag existen dos ideas que permiten movilizar a las personas frente a lo que las imágenes representan: la primera es que la atención pública está guiada por las focalizaciones que los medios de comunicación hacen del mundo y sus realidades. Los medios denotan la realidad de modo concluyente: a través de imágenes. Cuando hay fotografías, imágenes "del momento en que sucedieron los hechos", entonces, y parece que solo entonces, la guerra se vuelve "real" para muchos espectadores. El régimen de representación de lo realsocial que se expresa por medio de la fotografía periodística, también incide en la definición de aquello que nos preocupa como sociedad y en el tipo de evaluaciones que podemos hacer de los conflictos. 
La segunda idea que propone Sontag podría parecer contraria a la primera, y se refiere al "efecto de saturación". Las imágenes de la guerra deberían importar al ciudadano, por reflejar el dramatismo y el terror que producen los conflictos bélicos, pero tienen un efecto cada vez menor en la sensibilidad del público, entre otras porque la reiteración de la imagen de guerra (reiteración que es reforzada con otras imágenes de guerra producidas en los estudios de cine y televisión) nos vuelve insensibles: "En última instancia, tales imágenes solo nos incapacitan un poco más para sentir, para que no nos remuerda la consciencia" (Sontag, 2003, p. 46).

Esta idea de la posible insensibilización del público por la vía de la saturación es, por supuesto, muy limitada. La misma Sontag señala no estar tan segura de dicha afirmación, sobre todo porque es difícil demostrar el impacto que las imágenes de guerra generan en la sensibilidad del sujeto, y, por extensión, sobre la manera como esta se atenúa en una supuesta cultura del espectador que neutraliza la fuerza moral de las fotografías de atrocidades.

En la obra de Abad también hay un interés por los rastros de la guerra, por las situaciones e impactos que ella produce en la rota cotidianidad de las gentes, en los lugares más inhóspitos del país. Abad muestra un interés por la memoria de las gentes, comunidades y territorios olvidados, y le apuesta a hacer de los dramas del país "historias de más de un día". En este sentido, su fotografía es un documento de la tragedia que se vive en un país lleno de riquezas, pero que al mismo tiempo, y quizás por ello, mantiene a sus gentes más humildes en un completo olvido y a merced de múltiples actores y factores que contribuyen en el desarrollo y la afirmación de la violencia. 
Fotografía 6. Jesús Abad Colorado (1999). El desembarco.

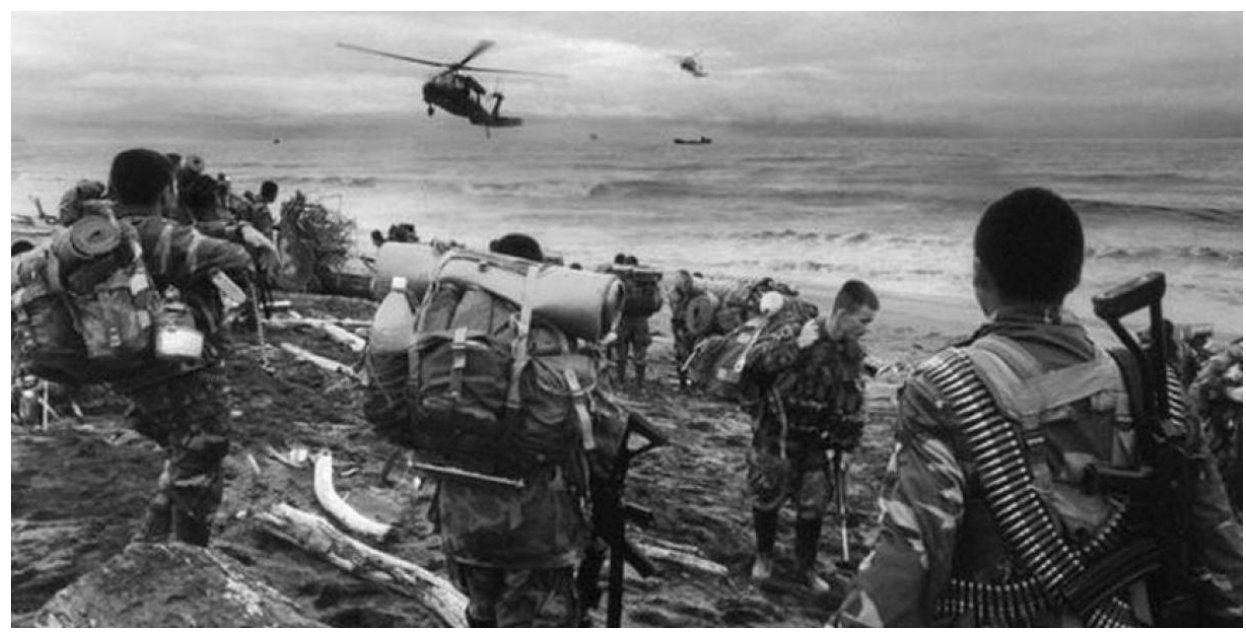

En la fotografía "El desembarco" se ve, por ejemplo, todo el aparataje de las operaciones militares. Para el ańo 2017 el gasto militar en Colombia fue del $3.1 \%$ del PIB, equivalentes a USD\$ 9.713 millones, según informe del Instituto Internacional de Estudios para la Paz de Estocolmo (Sipri), lo que ubica a Colombia como la nación suramericana que más dinero invierte en el sector militar. Esto, por supuesto, contrasta con los niveles de desigualdad y pobreza que para entre los años 2015 y 2016 fueron de un 28 \% de la población en promedio, según informes de la Cepal. La fotografía evidencia estas contradicciones, las hace públicas y testimonia no solo el horror de la guerra, sino también el horror del olvido, de la negligencia estatal, de las contradicciones de los actores armados y, por qué no, de la inmovilidad de amplios sectores de la sociedad civil. La fotografía: "aporta a la de-construcción de un orden simbólico instituido alrededor de la guerra y de quienes la hacen, con imágenes e historias de otros espacios construidos por hombres y mujeres que hacen de la risa, la palabra, el trabajo y la vida, esperanza y creación" (Roca, 2001).

Recordemos que para Sontag es importante permitir "que las imágenes atroces nos persigan", para lograr romper con el defecto moral que impone la ignorancia y la amnesia. Pero ella también defiende la idea del agotamiento de la fuerza de la imagen, sobre todo a partir del uso que de ella hace la televisión. El modo en que se 
emplea la imagen, la frecuencia con que se le expone socialmente, el modo de hacerlo, etcétera, agota la fuerza de una imagen: "las imágenes mostradas en la televisión son, por definición, imágenes de las cuales, tarde o temprano, nos hastiamos" (Sontag, 2003, p. 46). Así, lo que llamamos insensibilidad, tiene su origen en que la televisión está organizada para incitar y saciar la atención inestable del sujeto-observador, por medio de un hartazgo de imágenes:

Su superabundancia mantiene la atención en la superficie, móvil, relativamente indiferente al contenido. El flujo de imágenes excluye la imagen privilegiada. Lo significativo de la televisión es que se puede cambiar de canal, que es normal cambiar de canal, sentirse inquieto, aburrido. Los consumidores se desaniman. Necesitan ser estimulados, echados a andar, una y otra vez. El contenido no es más que uno de esos estimulantes (Sontag, 2003, p. 46).

Por ello es necesario, como dice Sontag, entablar un vínculo más reflexivo con el contenido de la imagen fotográfica, lo que precisa una determinada intensidad de la atención, "justo la que se ve disminuida por las expectativas inducidas en las imágenes que diseminan los medios, cuya lixiviación de contenido es lo que más contribuye a que se angoste el sentimiento" (Sontag, 2003, pp. 46-47). Para Sontag, debemos permitir que las imágenes atroces nos persigan, con el fin de romper con el defecto moral de ignorancia o amnesia que el hartazgo de imágenes atroces nos ofrece, entre otras porque el consumo de estas imágenes contribuye a que, como diría Noam Chomsky, "la gente ya no crea en los hechos" (Martínez, 2018), es decir, que la gente ya no crea en las pruebas atroces de lo que unos seres humanos son capaces de infligir a otros.

¿Es necesario continuar mostrando los actos atroces de la guerra por medio de imágenes, aunque solo se trate de muestras y no consiga abarcar el dramatismo de la realidad a que se refieren? Por supuesto, no se trata de pensar que la fotografía tiene como propósito remediar la insensibilidad y la amnesia que produce la sobrecarga de imágenes sin sentido; se trata más bien de reconocer que tales imágenes pueden ser una invitación a prestar atención, a reflexionar, a aprender, a examinar e interrogar no solo los hechos a los que remiten, sino también a cuestionar las racionalidades 
que se construyen sobre lo que significa el sufrimiento y su incorporación a la esfera pública por la vía de las imágenes.

Fotografía 7. Jesús Abad Colorado. Paramilitar de las Autodefensas Campesinas de Córdoba y Urabá (ACCU).

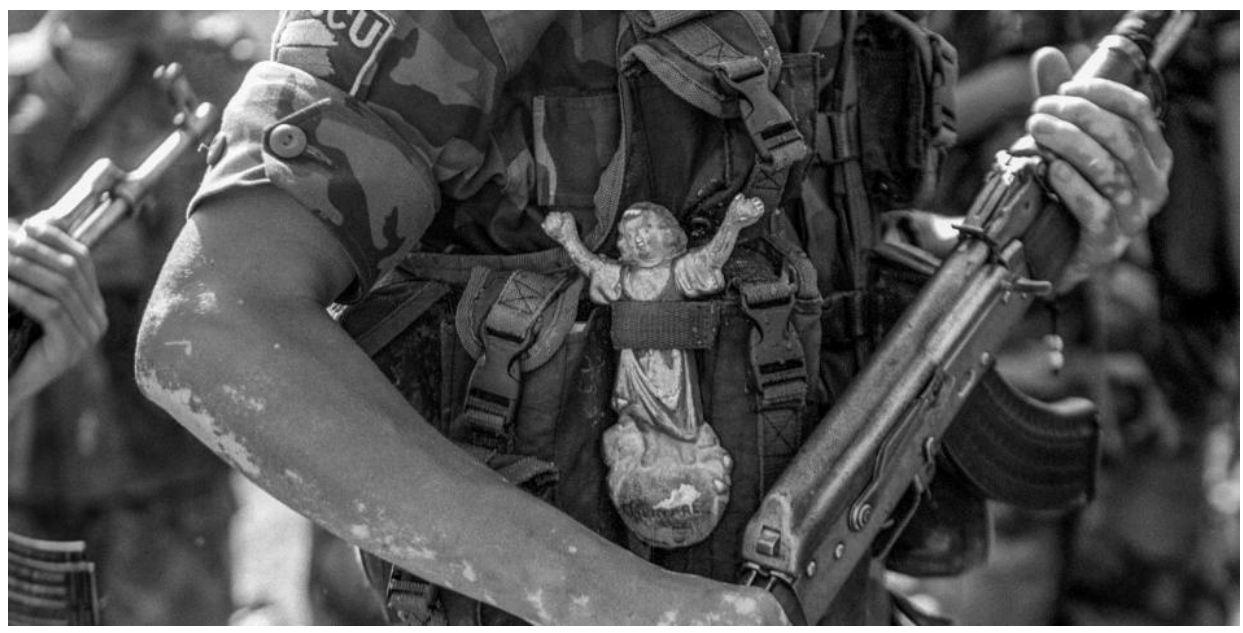

Si se quiere, la fotografía de guerra se convierte en artífice de la interrogación del mundo, en cuestiones como las responsabilidades, los contextos, los impactos, los actores que participan de aquello cruel, atroz e inhumano que la imagen muestra, porque: "las imágenes dicen: esto es lo que los seres humanos se atreven a hacer, y quizá se ofrezcan a hacer, con entusiasmo, convencidos de que están en lo justo. No lo olvides" (Sontag, 2003, p. 50).

En el fondo, lo que preocupa tanto a Susan Sontag como a Jesús Abad es el uso exhibicionista que la sociedad hace de la guerra y uno de sus productos más desoladores: sus imágenes. Pero más allá de las instancias del consumo, para quienes las realizan y analizan, estas imágenes se convierten en insumo para la denuncia del sufrimiento ajeno. Quizás, como dice Sontag, las únicas personas con derecho a ver imágenes de sufrimiento extremo que producen las guerras sean aquellas que pueden hacer algo para aliviarlo. 
Para Abad la fotografía es un documento social y político que permite activar la memoria colectiva en torno a los hechos de la guerra desde la perspectiva de las víctimas. Por su parte, Sontag le atribuye a la fotografía la capacidad de interpelar la memoria, pero también la mirada del fotógrafo en torno al fragmento de realidad que documenta, porque los retratos de violencia son al mismo tiempo llamativos y repugnantes, por ello, el interés de reconstruir el contexto de lo que se retrata e incluso de lo que sintió el fotógrafo en el momento de tomar la foto de esas imágenes donde unos hacen daños atroces a otros.

\section{A MOdo DE CONCLUSIón}

El trabajo fotoperiodístico de Jesús Abad Colorado tiene un fuerte componente humanista. Le interesa mostrar aquello que la guerra no ha podido destrozar, ni ocultar, ni envilecer. Da cuenta de eso que algunos llaman el "lado humano de la guerra”, en contra de los regímenes de representación mediática de la imagen, que quieren imponer a la guerra como alternativa para la resolución de los conflictos, o quieren hacer de ella un espectáculo solo para el consumo masivo.

El diálogo propuesto entre las obras de Jesús Abad y Susan Sontag permite identificar cómo los regímenes de representación de la guerra pretenden imponerse como consciencia que instrumentaliza el sufrimiento humano, es un régimen de la imagen al que le incomoda la diferencia y la complejidad de los conflictos, por lo que busca simplificarlos. Esto lleva a que se construya un síndrome de indolencia del público frente a las víctimas de la guerra, y frente a los contextos sociales, político-ideológicos, culturales y económicos en los que se le fundamenta.

El trabajo fotográfico de Abad coincide con los postulados generales de Sontag, a quien le interesaba la fotografía como testigo del sufrimiento, sin embargo, su trabajo va más allá y hace frente a lo que Sontag denomina como el "efecto de saturación", ya que intenta reconstituir las lógicas de producción y consumo de imágenes de guerra que pretende imponer el régimen de representación hegemónico, pero imprimiendo a su vez imágenes con un carácter humano, en el que se presenta la guerra más allá de los muertos. 
En este sentido, Abad no pretende impactar al público mostrando solamente los cuerpos mutilados (lo hace), sino que también dirige el lente hacia el entorno en el que se inscribe la imagen, intentando dilucidar aquello que ha permitido la violencia a la que ella remite.

Con esto se busca "curar" la insensibilidad pública frente a los acontecimientos de violencia, y frente a la carga simbólica que implican las imágenes del conflicto armado y social, más allá de la imagen misma. Porque la foto periodística es en la medida de lo que dice y explica, en un entorno en el que la saturación de imágenes ha dejado al espectador desprovisto de recursos para interpretar el contexto en el que ellas se inscriben, y que generan lo que Sontag ha denominado como el "hartazgo de las imágenes".

Tanto Sontag como Abad asumen la premisa de "dejar que las imágenes atroces nos persigan". Pero no solo ellas, sino todo aquello que ha posibilitado el acto de violencia que antecede a la imagen, y todo aquello que posibilita que el espectador ya no se conmueva con las imágenes que consume. Se trata de restituir el carácter de credibilidad y legitimidad al que remiten las imágenes de la guerra, para intentar explicar el porqué del horror que unos seres humanos son capaces de infligir a otros.

\section{REFERENCIAS}

Águila, M. (2006). También en la guerra los pobres son los perdedores. SwissInfo.ch. Recuperado de https://goo.gl/DMshjt

Baracaldo, D. (2014). El fotógrafo que más ha retratado el infierno de la guerra en Colombia. KienyKe. Recuperado de https://goo.gl/oyPD2k

Cuevas, A. M. (2012). Jesús Abad Colorado, guardián de la memoria. Periódico El Espectador. Recuperado de https://goo.gl/rju $4 \mathrm{kw}$ 
Fernández, F. (2002). El análisis de contenido como ayuda metodológica para la investigación. Revista de Ciencias Sociales CR, 2(96), 35-53. Cita de Díaz y Navarro (1998, p. 36). Recuperado de http://www.redalyc.org/pdf/153/15309604.pdf.

Fuenzalida, V. (2012). Una interpretación socio-semiótica de la representación televisiva de la política: la oportunidad de la TV digital. Cuadernos de Información, 1(30). DOI: https://doi.org/10.7764/cdi.30.428

Ibáñez, T. (1994). Representaciones sociales. Teoría y método. En: Psicología social construccionista. México, D. F., México: Universidad de Guadalajara. Pp. 153216. Recuperado de https://goo.gl/yBF4hy

Marfil-Carmona, R. (2015). Análisis de la imagen fotográfica en la comunicación digital de las ONG. Revista Opción, 31(5), 496-515. Recuperado de http://www. redalyc.org/pdf/310/31045570030.pdf

Martínez, J. (2018). Noam Chomsky: “La gente ya no cree en los hechos”. Diario El País. (elpais.com). Recuperado de https://goo.gl/V3su16

Pariente, J. L. (s. f.). La invención de la fotografía. Recuperado de https://goo.gl/ gLyDeu

Real Academia Española - RAE (2017). 23 Edición del Diccionario de la Lengua Española. Edición del tricentenario. Consultado en http://dle.rae.es.

Roca, J. (2001). Jesús Abad Colorado. (Columna de arena, n. $\left.{ }^{\circ} 34\right)$. Recuperado de http://www.universes-in-universe.de/columna/col34/col34.htm\#2.

Sánchez, A. (2017). Jesús Abad Colorado: desde el ángulo de la dignidad. Bitácora EAFIT. Recuperado de https://goo.gl/1cWJ3T

Sontag, S. (2003). Ante el dolor de los demás. Madrid, España: Santillana Ediciones Generales, S. L. 


\section{Lista de fotografías}

Fotografía 1. Jesús Abad Colorado (2002). Barrio La Independencia, Comuna 13, Medellín. (El Museo Galería). Recuperado de https://www.galeriaelmuseo.com/ archives/245/

Fotografía 2. Jesús Abad Colorado (2000). San Vicente del Caguán, Caquetá. (nebula.wsimg.com). Recuperado de https://goo.gl/FScWjK

Fotografía 3. Jesús Abad Colorado (2002). Masacre de Bojayá, Chocó. Pacifista. Recuperado de https://goo.gl/fwiYE4

Fotografía 4. Jesús Abad Colorado (1999). Toma de la vía Panamericana en el Cauca por parte de campesinos e indígenas. Revista Semana. Recuperado de https://goo. $\mathrm{gl} / \mathrm{hXuRfh}$

Fotografía 5. Jesús Abad Colorado (2001). Municipio de Peque, Antioquia. Revista Semana. Recuperado de https://goo.gl/GsXtcJ

Fotografía 6. Jesús Abad Colorado (1999). El desembarco. (img.elcomercio.pe). Recuperado de https://goo.gl/sXiGuq

Fotografía 7. Jesús Abad Colorado. Paramilitar de las Autodefensas Campesinas de Córdoba y Urabá (ACCU). Revista Semana. Recuperado de https://goo.gl/ P71MWs 